\title{
Development of one-step SYBR Green real-time RT-PCR for quantifying bovine viral diarrhea virus type- 1 and its comparison with conventional RT-PCR
}

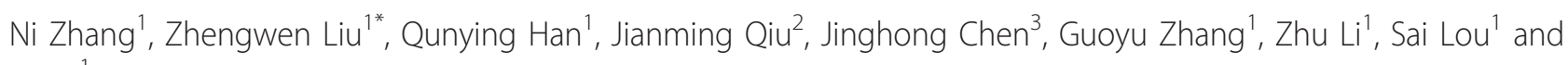
$\mathrm{Na} \mathrm{Li}{ }^{1}$

\begin{abstract}
Background: Bovine viral diarrhea virus (BVDV) is a worldwide pathogen in cattle and acts as a surrogate model for hepatitis $\mathrm{C}$ virus $(\mathrm{HCV}$ ). One-step real-time fluorogenic quantitative reverse transcription polymerase chain reaction (RT-PCR) assay based on SYBR Green I dye has not been established for BVDV detection. This study aims to develop a quantitative one-step RT-PCR assay to detect BVDV type-1 in cell culture.

Results: One-step quantitative SYBR Green I RT-PCR was developed by amplifying CDNA template from viral RNA and using in vitro transcribed BVDV RNA to establish a standard curve. The assay had a detection limit as low as 100 copies/ml of BVDV RNA, a reaction efficiency of 103.2\%, a correlation coefficient $\left(R^{2}\right)$ of 0.995 , and a maximum intra-assay CV of $2.63 \%$. It was 10 -fold more sensitive than conventional RT-PCR and can quantitatively detect BVDV RNA levels from 10 -fold serial dilutions of titrated viruses containing a titer from $10^{-1}$ to $10^{-5} \mathrm{TCID}_{50}$, without nonspecific amplification. Melting curve analysis showed no primer-dimers and non-specific products.

Conclusions: The one-step SYBR Green I RT-PCR is specific, sensitive and reproducible for the quantification of BVDV in cell culture. This one-step SYBR Green I RT-PCR strategy may be further optimized as a reliable assay for diagnosing and monitoring BVDV infection in animals. It may also be applied to evaluate candidate agents against HCV using BVDV cell culture model.
\end{abstract}

Keywords: Bovine viral diarrhea virus type-1, cRNA standard, SYBR Green I RT-PCR, Quantitation, Cell culture

\section{Background}

Bovine viral diarrhea virus (BVDV), the etiological agent of bovine viral diarrhea/mucosal disease, is a worldwide pathogen in cattle. Based on the characteristic of presence/absence of visual cytopathology in infected cells, BVDV has been segregated into two biotypes, cytopathic (CP) and noncytopathic (NCP). According to sequences from the 5'-nontranslated region (5'-NTR) of the viral genome, BVDV has been divided into two genotypes, types 1 and 2 [1,2]. BVDV infection results in diarrhea,

\footnotetext{
* Correspondence: liuzhengwen@medmail.com.cn

'Department of Infectious Diseases, First Affiliated Hospital, School of Medicine, Xi'an Jiaotong University, Xi'an 710061, Shaanxi Province, the People's Republic of China

Full list of author information is available at the end of the article
}

acute and chronic mucosal disease, persistent infection and immunotolerance, immunosupression, pregnant cow abortion, dead fetus and abnormal fetus. Having not been controlled by classical vaccination, BVDV seriously endangers the cattle herds [1].

BVDV belongs to the genus Pestivirus of the family Flaviviridae, which also comprises the genera Flavivirus and Hepacivirus [3], and contains one single-stranded, plus-sense RNA genome of approximately $12.5 \mathrm{~kb}$ [4]. Hepatitis $\mathrm{C}$ virus (HCV) belongs to the same family Flaviviridae with BVDV and the genomes of $\mathrm{HCV}$ and BVDV both consist of a $5^{\prime}$-NTR, a single open reading frame and a 3'-nontranslated region (3'-NTR) [5]. Both viruses may cause chronic infections in their respective hosts. Thus, BVDV, especially the type 1 NADL strain, 
also acts as a surrogate model of HCV based on all these similarities and the feasibility to be cultured in vitro [6,7]. Therefore, a high-throughput assay for precise detection of BVDV was essential not only for the diagnosis and disease evaluation of BVDV infected animals but also for the screening of candidate anti-HCV agents in cell culture.

Serological assay such as enzyme-linked immunosorbent assay $[8,9]$ and molecular biological methods such as conventional reverse transcription-polymerase chain reaction (RT-PCR) [10-12] and nested PCR [13] for the detection of BVDV have been developed. However, serological assay is usually time-consuming and the results are not very accurate and specific [14]. RT-PCR is sensitive and specific for the detection of BVDV, but the analysis of RT-PCR amplified fragment is usually followed by a procedure of agarose gel electrophoresis, which may result in contamination of amplified products in the laboratory. With the advent of real-time fluorogenic quantitative PCR (FQ-PCR), TaqMan-PCR for the detection of BVDV has been developed [15-17]. In comparison with TaqMan-PCR, SYBR Green PCR assay, a realtime FQ-PCR technique using SYBR Green I dye, has the advantages of being easy to design, relatively low setup and running costs [18] and possibly more precise results and linear decay plot [19]. Two-step SYBR Green I RT-PCR assay has been used to detect BVDV [20]. However, one-step real-time fluorogenic quantitative RT-PCR assay based on SYBR Green I dye has not been established for BVDV detection.

The present study developed a high-throughput onestep SYBR green I real-time quantitative RT-PCR assay for the detection of BVDV type 1 in cell culture and obtained the copy numbers of virus using a constructed RNA standard curve. The performance of the one-step SYBR Green I RT-PCR assay was also evaluated.

\section{Materials and methods}

\section{Cells and virus}

Primary calf testis (CT) cells were prepared from healthy newborn calf as described elsewhere [21]. Experimental procedures were approved by the Institutional Animal Care and Use Committee of Xi'an Jiaotong University.

Cytopathic BVDV (type 1, strain NADL, National Animal Disease Laboratory, Ames, Iowa, USA) was purchased from China Institute of Veterinary Drugs Control (Beijing, China) with the virus dilution in serum-free MEM.

\section{Virus titration}

Cells at $80 \%$ confluence in a 96 -well plate were infected with the virus at a series of dilutions from $10^{-1}$ to $10^{-9}$ with eight wells for each dilution, and were maintained at $37^{\circ} \mathrm{C}$ in $5 \% \mathrm{CO}_{2}$ for $134 \mathrm{~h}$. The titer of $50 \%$ tissue culture infective dose of virus $\left(\mathrm{TCID}_{50}\right)$ was calculated with the method of Reed-muench [22].

\section{RNA isolation}

CT cells incubated in $25 \mathrm{ml}$ culture flask at $37^{\circ} \mathrm{C}$ in $5 \%$ $\mathrm{CO}_{2}$ and grown into $80 \%$ to $90 \%$ cell confluence were infected with BVDV and incubated for $110 \mathrm{~h}$. When $100 \%$ CPEs was seen, the cells were frozen and thawed 3 times at $-80^{\circ} \mathrm{C}$, and then the supernatant was collected, clarified by centrifugation $(1,000 \times g)$ and stored at $-80^{\circ} \mathrm{C}$ for RNA extraction. Viral RNA used for the construction of cRNA standards for BVDV RNA was extracted from the supernatants using the QIAamp viral RNA mini kit according to the manufacturer's instructions (QIAGEN China Co., Ltd. Shanghai, China). Viral RNAs from a series of dilutions from $10^{2} \mathrm{TCID}_{50}$ to $10^{-5} \mathrm{TCID}_{50}$ were also extracted for further experiment.

\section{Construction of CRNA standards for BVDV RNA Primer design and modification for $P C R$}

Referring to the BVDV sequence (GeneBank accession no. M31182), the primer pairs specific for the BVDV NS5B region were designed as 5'-ACACCAAAGCCTGGGACACT-3' (position 11226-11245 of the NADL sequence) and 5'-CTCCCTCTCTGCCCATTTCTT-3' (position 11386-11406 of the NADL sequence). The forward primer was modified with the incorporation of a $\mathrm{T} 7$-promoter sequence (5'-TAATACGACTCACTATAGGG-3') onto the 5'-end of the primer. The modification was essential for performing in vitro transcription with the T7 RNA polymerase followed. The modified forward primer and the reverse primer were used for the construction of cRNA standards. The primers were synthesized and purified by TaKaRa (TaKaRa Dalian Biotechnology Co., Ltd. Dalian, China). The RNA standards constructed had a size of 184 base (nt. 11226 to 11406 of BVDV sequence and 3 base T7-promoter sequence).

\section{Amplification of CDNA template for in vitro transcription by} $R T-P C R$

Viral RNA from cell cultures was taken for cDNA synthesis. RNA PCR Kit (AMV) (TaKaRa Dalian Biotechnology Co., Ltd. Dalian, China) was used for RTPCR according to the manufacturer's instructions. Reverse transcription (RT) was performed in a final volume of $10 \mu \mathrm{l}$, containing $0.5 \mu \mathrm{l}$ random 9 mers, $2 \mu \mathrm{l}$ $\mathrm{MgCl}_{2}(2.5 \mathrm{mM}), 1 \mu \mathrm{l} 10 \times$ RNA PCR buffer, $1 \mu \mathrm{l}$ dNTP mixture, $0.25 \mu \mathrm{l}$ RNase inhibitor, $0.5 \mu \mathrm{l}$ AMV reverse transcriptase $(5 \mathrm{U} / \mu \mathrm{l}), 4 \mu \mathrm{l}(3 \mu \mathrm{g})$ of viral RNA and 0.75 $\mu \mathrm{l}$ DEPC-treated $\mathrm{H}_{2} \mathrm{O}$. RT was performed with the following program: $10 \mathrm{~min}$ at $30^{\circ} \mathrm{C}, 30 \mathrm{~min}$ at $42^{\circ} \mathrm{C}, 5 \mathrm{~min}$ at $99^{\circ} \mathrm{C}$ and $5 \mathrm{~min}$ at $5^{\circ} \mathrm{C}$. PCR was performed in a total reaction volume of $50 \mu \mathrm{l}$ reaction mixture by adding 40 $\mu \mathrm{l}$ of the mixture, containing $10 \mu \mathrm{l}$ of $5 \times$ PCR buffer, $28.75 \mu \mathrm{l}$ of sterilized distilled water, $0.25 \mu \mathrm{l}$ of TaKaRa 
Ex $\mathrm{Taq}^{\mathrm{TM}} \mathrm{HS}$ and $0.5 \mu \mathrm{l}$ of each primer $(20 \mu \mathrm{M})$ as described above for constructing BVDV cRNA standards, into the tube containing $10 \mu \mathrm{l}$ T products. PCR was performed in a cycling condition as follows: $2 \mathrm{~min}$ at $94^{\circ} \mathrm{C}$ followed by 30 cycles of $30 \mathrm{sec}$ at $94^{\circ} \mathrm{C}, 1 \mathrm{~min}$ at $55^{\circ} \mathrm{C}$ and $1 \mathrm{~min}$ at $72^{\circ} \mathrm{C}$ with a final step at $72^{\circ} \mathrm{C}$ for 3 min to allow complete extension of all amplified fragments. The amplified products had an expected size of $201 \mathrm{bp}$ on $1 \%$ agarose gel electrophoresis.

\section{In vitro transcription}

PCR products amplified with the modified primer pairs were used as the template to synthesize complementary RNA (cRNA) by in vitro transcription with T7 RNA polymerase after being purified by ethanol precipitation. In vitro transcription T7 Kit (TaKaRa Dalian Biotechnology Co., Ltd. Dalian, China) was applied according to the manufacturer's protocol. The RNA standards obtained were stored at $-80^{\circ} \mathrm{C}$ until use.

\section{Quantification of the RNA standards}

The OD value of RNA standard concentrations was measured at $260 \mathrm{~nm} / 280 \mathrm{~nm}$ on Thermo Scientific NanoDrop ${ }^{\text {TM }} 1000$ Spectrophotometer (NanoDrop Technologies, LLC, Wilmington, DE, USA). The viral RNA genomic copy number of the RNA standards was calculated according to the following formula: RNA copy number $($ copies $/ \mu \mathrm{l})=$ RNA concentration $(\mathrm{g} / \mu \mathrm{l}) \times$ $6.02 \times 10^{23} / 345 \times$ RNA length (b).

\section{One-step quantitative real-time RT-PCR}

The RNA standards were used to construct standard curves spanning $10^{7}-10^{2}$ copies $/ \mathrm{ml}$ by 10 -fold serial dilutions. One-step quantitative real-time RT-PCR (Q-RTPCR) was performed by One-step SYBR ${ }^{\circledR}$ PrimeScript ${ }^{\mathrm{TM}}$ RT-PCR Kit II (Perfect Real Time, TaKaRa Dalian Biotechnology Co., Ltd. Dalian, China) on Bio-Rad iQ5 Multicolor Real-Time PCR Detection System (170-9780, BIORAD Laboratories, Hercules, CA, USA). The forward primer and reverse primer were synthesized and purified by TaKaRa (TaKaRa Dalian Biotechnology Co., Ltd. Dalian, China), and the sequences were 5'-TGACACCATCACCGACCAC-3' (position 11323-11341 of the NADL sequence) and 5'-CTCCCTCTCTGCCCATTTCTT-3' (position 11386-11406 of the NADL sequence), respectively, amplifying a $84 \mathrm{bp}$ fragment. Reverse transcription was carried out in a condition of $5 \mathrm{~min}$ at $42^{\circ} \mathrm{C}$ and $10 \mathrm{sec}$ at $95^{\circ} \mathrm{C}$, and PCR reaction was performed 40 cycles of 5 sec at $95^{\circ} \mathrm{C}$ and $30 \mathrm{sec}$ at $60^{\circ} \mathrm{C}$.

\section{Validation of reproducibility of one-step SYBR Green I RT-} PCR assay

To assess the intra-assay and the inter-assay variability, RNA standards from $1 \times 10^{7}$ to $1 \times 10^{2}$ copies $/ \mathrm{ml}$ and titrated viruses at different dilutions were tested by onestep SYBR Green I RT-PCR assay in triplicate in a single assay (intra-assay) and at three different days (interassay). The coefficient of variation (CV) of threshold cycle $(\mathrm{Ct})$ was determined.

\section{Validation of specificity of one-step SYBR Green I RT-PCR assay}

To differentiate specific from nonspecific amplified products, the amplified products obtained by one-step SYBR Green I RT-PCR assay were identified by analysis of melting peaks of BVDV RNA standards from $1 \times 10^{7}$ to $1 \times 10^{2}$ copies $/ \mathrm{ml}$ and titrated viruses at different dilutions.

\section{Conventional RT-PCR}

The forward primer and reverse primer with the same sequences as those used in one-step SYBR Green I RTPCR assay were synthesized and purified by TaKaRa (TaKaRa Dalian Biotechnology Co., Ltd. Dalian, China). Viral RNA at a volume of $2 \mu \mathrm{l}$ from titrated viruses at 10fold serial dilutions was tested by RT-PCR with RNA PCR Kit (AMV) (TaKaRa Dalian Biotechnology Co., Ltd. Dalian, China) on MJ research PTC-200 peltier thermal cycler (APE-BridgePath Scientific, Frederick, MD, USA) according to the manufacturer's instructions. Complementary DNA was synthesized using viral RNA as template by reverse-transcriptase in a program consisted of $10 \mathrm{~min}$ at $30^{\circ} \mathrm{C}, 30 \mathrm{~min}$ at $42^{\circ} \mathrm{C}, 5 \mathrm{~min}$ at $99^{\circ} \mathrm{C}$ and $5 \mathrm{~min}$ at $5^{\circ} \mathrm{C}$ and subsequently amplified by PCR in the program including an initial denaturation step at $94^{\circ} \mathrm{C}$ for $5 \mathrm{~min}$, followed by 40 cycles with denaturation at $94^{\circ} \mathrm{C}$ for 30 sec, annealing at $60^{\circ} \mathrm{C}$ for $30 \mathrm{sec}$ and extension at $72^{\circ} \mathrm{C}$ for $45 \mathrm{sec}$, and a final extension at $72^{\circ} \mathrm{C}$ for $5 \mathrm{~min}$.

\section{Comparisons of one-step SYBR Green I RT-PCR and conventional RT-PCR}

Serial dilutions of the viral titrations detected by onestep SYBR Green I RT-PCR and conventional RT-PCR in parallel were compared. The amplified products were electrophoresed on $2.5 \%$ agarose gels and the optical density (OD) of the image was analyzed with UVP BioImaging Systems by LabWorks Image Acquisition and Analysis Software 4.0 (Ultra-Violet Products Ltd., Cambridge, UK).

\section{Statistical analysis}

All data were analyzed using statistical software SPSS13.0 (SPSS Inc., Chicago, IL, USA). Inter-group comparison of OD values was analyzed by Student's t test with significance level $\alpha=0.05$.

\section{Results}

Complementary DNA template for in vitro transcription The amplification of viral RNA from cell cultures by RT-PCR successfully obtained the cDNA template for in 
vitro transcription with a size of 201 bp on $1 \%$ agarose gel (Figure 1a), which was in accordance with the expected size.

\section{Transcripts quantification of RNA standards}

In vitro transcription with T7 RNA polymerase using the cDNA template successfully generated the cRNA transcripts, which had a size in accordance with the expected $184 \mathrm{~b}$ on $3 \%$ agarose gel (Figure $1 \mathrm{~b}$ ).

\section{Quantification of RNA standards}

The concentration of RNA standards was quantified to be $205.6(\mathrm{ng} / \mu \mathrm{l})$ by spectrophotometer. The copy numbers of RNA standards were calculated to be $1.9 \times$ $10^{12}$ copies/ $\mu \mathrm{l}$ according to the formula as described above.

\section{Complementary RNA standard curves}

SYBR Green I PCR amplifications were performed to established standard curves for BVDV RNA using the serially diluted RNA standards obtained by in vitro transcription. The detection and quantification limits were determined using $\mathrm{Ct}$ values obtained by six serial dilutions ranging from $10^{7}$ to $10^{2}$ copies $/ \mathrm{ml}$ of the standard RNA (Figure 2a). The reaction efficiency of the assay using the slope (slope $=-3.247$ ) from the linear equation (copy number of the virus $=10^{(\mathrm{Ct}-38.561) / 3.247}$ ) was estimated to be $103.2 \%$. The correlation coefficient $\left(R^{2}\right)$ was 0.995 (Figure 2b).
Reproducibility of one-step SYBR Green I RT-PCR assay

The intra-assay and inter-assay variations of one-step SYBR Green I RT-PCR assay were summarized in Table 1. The maximum $\mathrm{CV}$ in the intra-assay tests was $2.63 \%$, demonstrating good reproducibility.

\section{Specificity of one-step SYBR Green I RT-PCR assay}

Melting peaks analysis on the PCR products of cRNA standards showed that there was no primer-dimers and non-specific products and only a single peak was visible in the melting peak chart (Figure 3a). There was also no non-specific amplification observed from 10 -fold serial dilutions of titrated virus known to be positive for BVDV (Figure 3b).

\section{Sensitivity comparison of one-step SYBR Green I RT-PCR with conventional RT-PCR}

BVDV RNA in 10-fold serial dilutions of titrated virus from $10^{2} \mathrm{TCID}_{50}$ to $10^{-5} \mathrm{TCID}_{50}$ were detected by onestep SYBR Green I RT-PCR and conventional RT-PCR in parallel. BVDV RNA in titrated virus at $10^{-5} \mathrm{TCID}_{50}$ quantitatively detected by one-step SYBR Green I RTPCR was equivalent to $8.79( \pm 1.18) \times 10^{2}$ copies $/ \mathrm{ml}$ of BVDV RNA.

The detection limit of conventional RT-PCR was $10^{-4}$ $\mathrm{TCID}_{50}$. The OD values of titrated virus at $10^{-1} \mathrm{TCID}_{50}$, $10^{-2} \mathrm{TCID}_{50}, 10^{-3} \mathrm{TCID}_{50}$ and $10^{-4} \mathrm{TCID}_{50}$ were $1295.77 \pm 127.06,1263.33 \pm 106.46,1359.53 \pm 80.14$ and $1340.00 \pm 11.09$, respectively. There was no

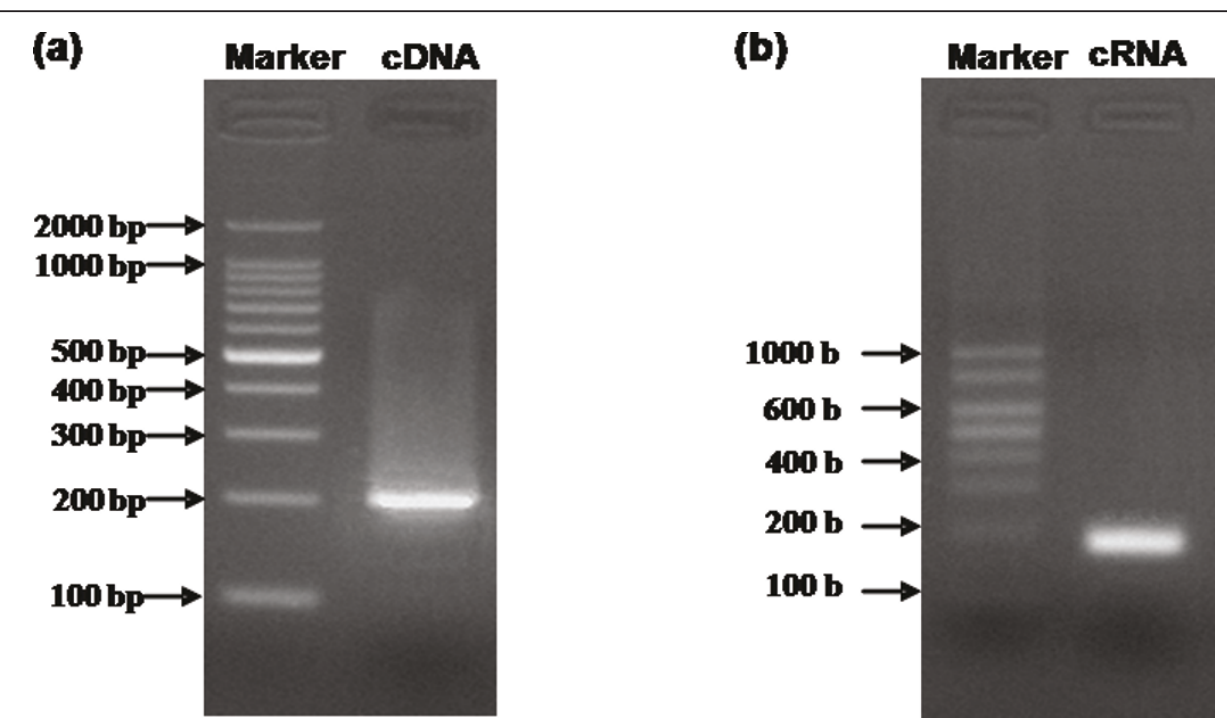

Figure 1 Agarose gel electrophoresis of cDNA template (a) and cRNA standard (b). (a) 1\% agarose gel electrophoresis of cDNA template synthesized by RT-PCR. Complementary DNA (CDNA) template with a length of 201 bp synthesized using viral RNA as template by reversetranscriptase and subsequently amplified by PCR. Marker: 100 bp DNA Ladders. (b) 3\% agarose gel electrophoresis of cRNA standard. Complementary RNA (CRNA) standard with a length of $184 \mathrm{~b}$ synthesized using the amplified CDNA as a template by in vitro transcription. Marker: RNA Marker RL1,000. 

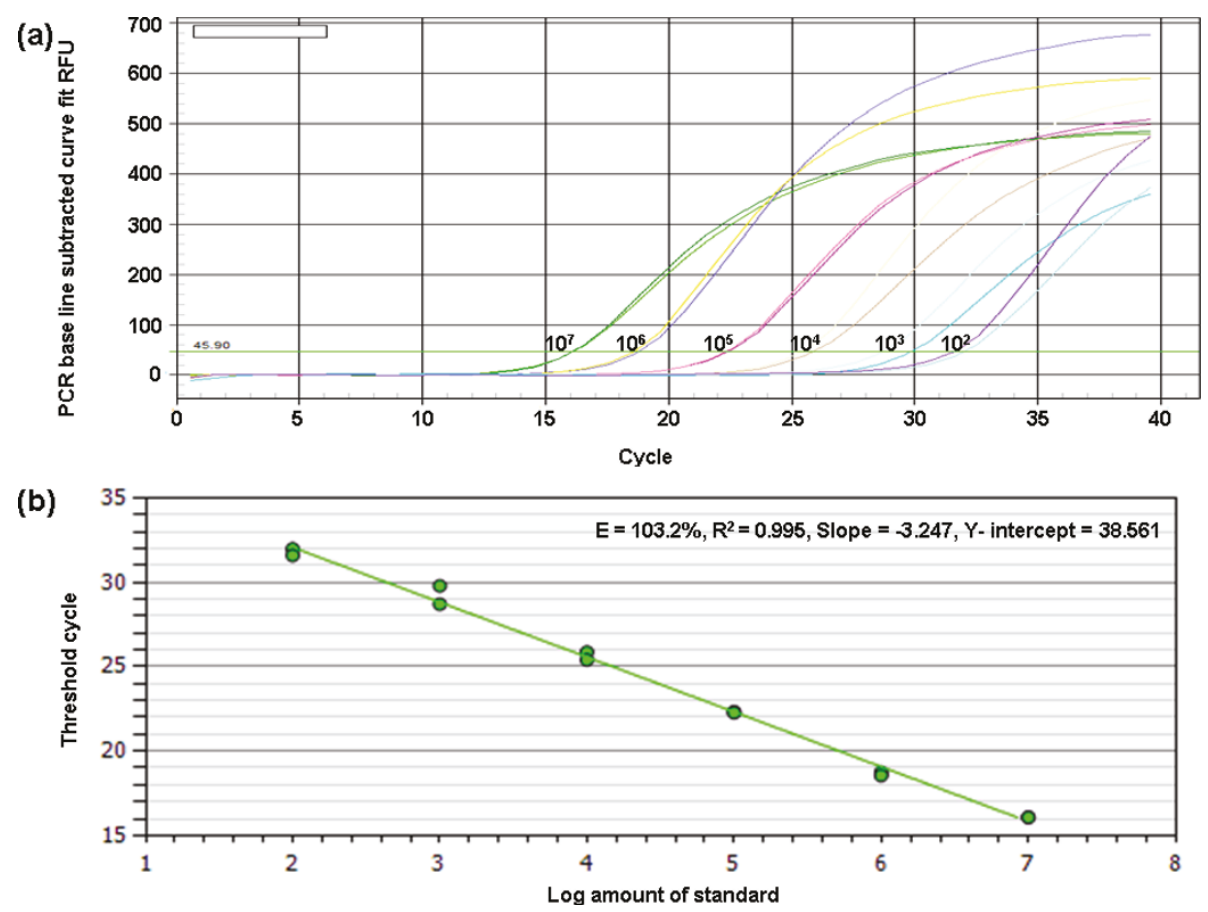

Figure 2 BVDV RNA melting curves (a) and BVDV RNA standard curve (b). (a) BVDV RNA melting curves showing 10-fold serial dilutions of standard RNA from $10^{7}$ to $10^{2}$ copies/ml amplified by SYBR Green RT-PCR on Bio-Rad iQ5 Multicolor Real-Time PCR Detection System. (b) BVDV RNA standard curve produced by SYBR Green RT-PCR on Bio-Rad iQ5 Multicolor Real-Time PCR Detection System using 10-fold serial dilutions of standard RNA transcribed in vitro as standard templates.

significant difference in OD values of PCR products by conventional RT-PCR between titrated virus at $10^{-1}$ $\mathrm{TCID}_{50}$ and at $10^{-4} \mathrm{TCID}_{50}(P=0.580)$, between titrated virus at $10^{-2} \mathrm{TCID}_{50}$ and at $10^{-4} \mathrm{TCID}_{50}(P=0.283)$, and between titrated virus at $10^{-3} \mathrm{TCID}_{50}$ and at $10^{-4}$ $\operatorname{TCID}_{50}(P=0.697)$ (Figure 4b).

Compared with conventional RT-PCR assay, one-step SYBR Green I RT-PCR assay was 10-fold more sensitive and could be used to quantitatively detect the levels of BVDV RNA from 10-fold serial dilutions of titrated virus from $10^{-1} \mathrm{TCID}_{50}$ to $10^{-5} \mathrm{TCID}_{50}$, which were $(9.67 \pm 0.36) \times 10^{3}$ copies $/ \mathrm{ml},(4.54 \pm 1.05) \times 10^{3}$ copies $/ \mathrm{ml},(2.64 \pm 0.75) \times 10^{3}$ copies $/ \mathrm{ml},(1.37 \pm 0.16) \times$
$10^{3}$ copies $/ \mathrm{ml}$ and $(8.79 \pm 1.18) \times 10^{2}$ copies $/ \mathrm{ml}$, respectively (Figure 4a). There were significant differences in the levels of the virus RNA between titrated virus at $10^{-}$ ${ }^{1} \mathrm{TCID}_{50}$ and at $10^{-2} \operatorname{TCID}_{50}(P=0.001)$, between titrated virus at $10^{-3} \mathrm{TCID}_{50}$ and at $10^{-4} \operatorname{TCID}_{50}(P=$ 0.046 ), between titrated virus at $10^{-4} \mathrm{TCID}_{50}$ and at $10^{-5}$ $\mathrm{TCID}_{50}(P=0.014)$ except those between titrated virus at $10^{-2} \mathrm{TCID}_{50}$ and at $10^{-3} \mathrm{TCID}_{50}$ which showed a marginal significance $(P=0.063)$.

\section{Discussion}

This study established CT cell culture system for BVDV proliferation. The specific primers for constructing

Table 1 Analytical reproducibility of one-step SYBR Green I RT-PCR assay in the inter- and intra- assay

\begin{tabular}{|c|c|c|c|c|c|c|c|c|c|}
\hline & $\begin{array}{l}\text { Levels of cRNA } \\
\text { (copies/ml) }\end{array}$ & & & & & & $\mathrm{TCID}_{50}$ & & \\
\hline & $10^{2}$ & $10^{3}$ & $10^{4}$ & $10^{5}$ & $10^{6}$ & $10^{7}$ & 10 & $10^{-2}$ & $10^{-5}$ \\
\hline \multicolumn{10}{|l|}{ The inter- assay } \\
\hline $\begin{array}{l}\text { Ct values (mean } \pm \\
\text { S.D.) }\end{array}$ & $31.63 \pm 0.276$ & $\begin{array}{l}29.31 \pm \\
0.482\end{array}$ & $\begin{array}{l}25.56 \pm \\
0.344\end{array}$ & $\begin{array}{l}22.19 \pm \\
0.286\end{array}$ & $\begin{array}{l}18.55 \pm \\
0.299\end{array}$ & $\begin{array}{l}15.95 \pm \\
0.300\end{array}$ & $\begin{array}{l}24.10 \pm \\
0.065\end{array}$ & $\begin{array}{l}26.71 \pm \\
0.570\end{array}$ & $\begin{array}{l}28.87 \pm \\
0.308\end{array}$ \\
\hline CV (\%) & 0.87 & 1.64 & 1.34 & 1.28 & 1.61 & 1.88 & 0.27 & 2.13 & 1.06 \\
\hline \multicolumn{10}{|l|}{ The intra- assay } \\
\hline $\begin{array}{l}\text { Ct values (mean } \pm \\
\text { S.D.) }\end{array}$ & $31.78 \pm 0.274$ & $\begin{array}{l}29.25 \pm \\
0.769\end{array}$ & $\begin{array}{l}25.63 \pm \\
0.327\end{array}$ & $\begin{array}{l}22.30 \pm \\
0.039\end{array}$ & $\begin{array}{l}18.65 \pm \\
0.142\end{array}$ & $\begin{array}{l}16.08 \pm \\
0.008\end{array}$ & $\begin{array}{l}24.11 \pm \\
0.046\end{array}$ & $\begin{array}{l}26.71 \pm \\
0.337\end{array}$ & $\begin{array}{l}29.01 \pm \\
0.266\end{array}$ \\
\hline CV (\%) & 0.86 & 2.63 & 1.27 & 0.17 & 0.76 & 0.05 & 0.19 & 1.26 & 0.91 \\
\hline
\end{tabular}



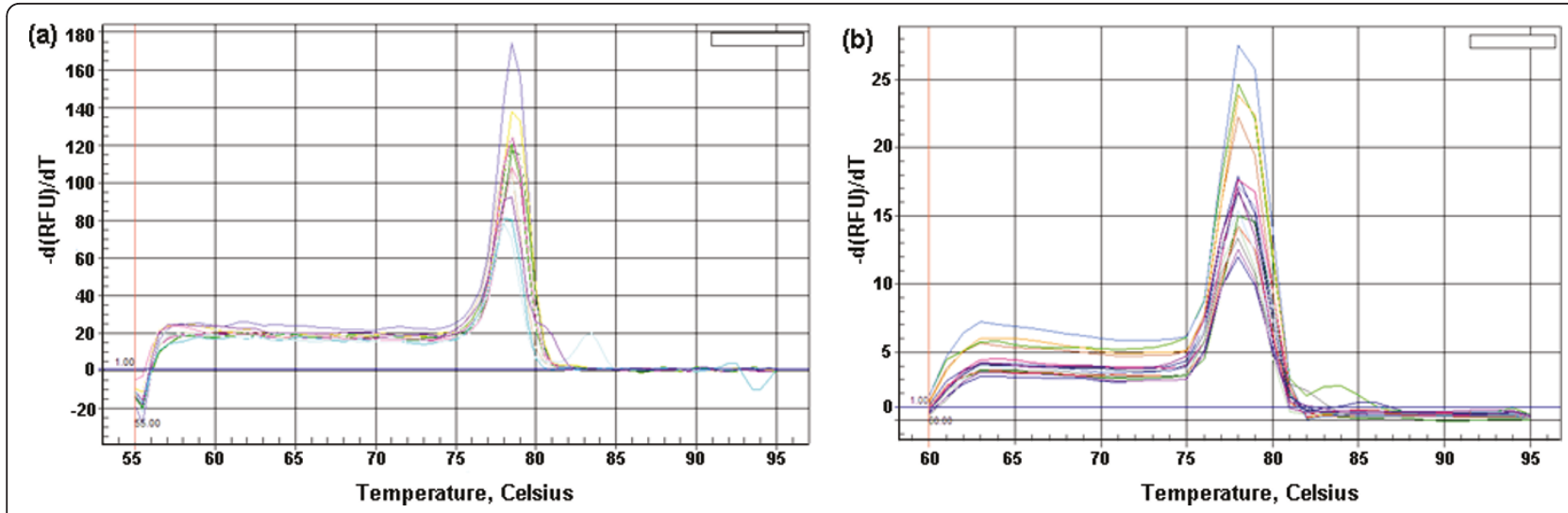

Figure 3 Melting peaks analysis on the PCR products of SYBR Green RT-PCR on Bio-Rad iQ5 Multicolor Real-Time PCR Detection System. (a) Melting peaks of PCR product from CRNA standards. (b) Melting peaks of PCR product from BVDV RNA of 10-fold serial dilutions of titrated virus.

cRNA standards and real-time RT-PCR were designed from the genomic sequence of the NS5B of BVDV genotype 1, NADL stain, whose sequence was different from that of BVDV genotype 2, resulting in characterization of BVDV type-1.

RNA standards in this study were generated using BVDV RNA in cell cultures by in vitro transcription with T7 RNA polymerase for quantifying BVDV RNA by real-time RT-PCR. A RNA standard curve with a linear range of $6 \log$ units was set up and quantitation from $10^{7}$ to $10^{2}$ copies of the standard RNA were determined. The levels of RNA from samples for inspection were quantified by extrapolation of fluorescence signals against standard curves representing the initial copy numbers for a defined fluorescence signal [23]. In addition to in vitro synthesis of cRNA standards as performed in this study, the standard curves are commonly obtained using plasmid clones containing the cDNA of the gene of interest as the template by quantitative PCR. Compared with plasmid clones, cRNA standards was applicable for measuring transcripts from any gene of interest and can be reverse-transcribed and amplified with RNA from samples in a parallel procedure using identical primer pairs.

For accurate quantification of PCR products, the slope of the standard curve obtained with 10-fold dilutions should approach -3.3 in theory, but a slope from -3.1 to -3.6 was acceptable in practice. Furthermore, the corresponding correlation coefficient should be $>0.95$ [24]. The correlation coefficient and the reaction efficiencies of the standard curve constructed in this study were 0.995 and $103.2 \%$, respectively. The slope from the linear equation was -3.247 , which was close to the theoretical slope of -3.3 , maintaining linearity for at least six orders of magnitude. The maximum CV with the mean Ct values of 29.25 was $2.63 \%$, demonstrating good reproducibility of the assay.

To evaluate the specificity of PCR products amplified, a melting curve analysis should be performed by detecting primer-dimers and non-specific products. The

(a)

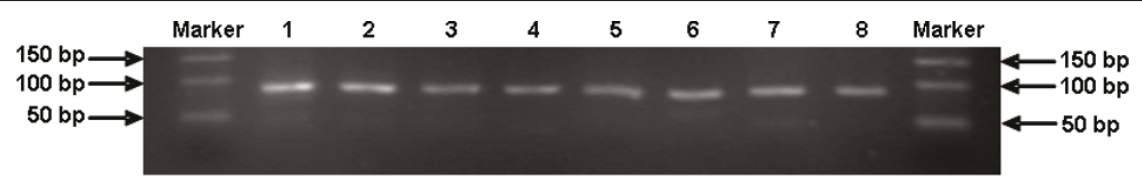

(b)

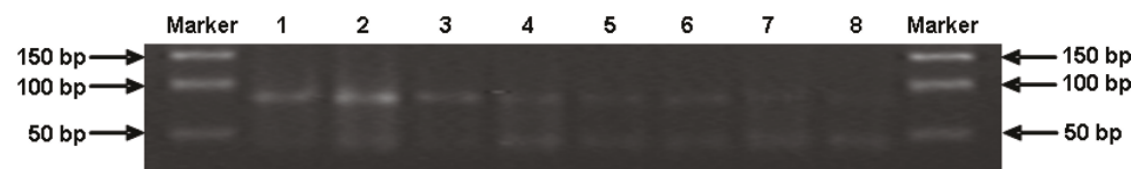

Figure 4 Comparison of one-step SYBR Green I RT-PCR with conventional RT-PCR for dectecting BVDV RNA of titrated viruses at 10fold serial dilutions. (a) $2.5 \%$ agarose gel electrophoresis of the amplified products with a length of 84 bp obtained by one-step SYBR Green I RT-PCR. Marker: 50 bp DNA Marker, Lane 1: $100 \mathrm{TCID}_{50}$, Lane 2: $10 \mathrm{TCID}_{50}$, Lane 3: 1 TCID 50 , Lane 4: $10^{-1} \mathrm{TCID}_{50}$, Lane 5: 10 $0^{-2} \mathrm{TCID}_{50}$, Lane 6: $10^{-3}$ $\mathrm{TCID}_{50}$, Lane 7: $10^{-4} \mathrm{TCID}_{50}$, Lane 8: $10^{-5} \mathrm{TCID}_{50}$. (b) 2.5\% agarose gel electrophoresis of the amplified products with a length of 84 bp obtained by conventional RT-PCR. Marker: DNA Marker DL 500, lane 1: $100 \mathrm{TCID}_{50}$, lane 2: $10 \mathrm{TCID}_{50}$, lane 3: $1 \mathrm{TCID}_{50}$, lane 4: $10^{-1} \mathrm{TCID}_{50}, \operatorname{lane}^{2}$ : $10^{-2}$ $\mathrm{TCID}_{50}$, lane 6: $10^{-3} \mathrm{TCID}_{50}$, lane $7: 10^{-4} \mathrm{TCID}_{50}$, lane 8: $10^{-5} \mathrm{TCID}_{50}$. 
specificity of PCR-amplified products was determined by only a single peak visible in the melting peak profile $[24,25]$. In this study, there was no evidence of non-specific amplification in melting curve of each sample, indicating a high specificity of the SYBR Green I RT-PCR assay for the detection of BVDV in cell culture.

The one-step SYBR Green I RT-PCR assay in this study was 10 -fold more sensitive than the conventional RT-PCR assay. It could discriminate most of the copy numbers of BVDV from $10^{-1} \mathrm{TCID}_{50}$ to $10^{-4} \mathrm{TCID}_{50}$ in their adjacent virus titers and detect the virus RNA as low as $10^{-5} \operatorname{TCID}_{50}$ which were unable to be differentiated or detected by conventional RT-PCR. Compared with conventional PCR assay, the SYBR Green I real-time PCR assay was a more efficient method with a lower detection limit and higher sensitivity [26]. It has also been demonstrated to be more rapid, sensitive and reliable than virus isolation by traditional cell culture [20].

The single-tube detection assay and one-step SYBR Green I real-time PCR assay were respectively developed for detecting the virus $[27,28]$. The SYBR Green I RTPCR assay established in this study was one-step realtime RT-PCR assay in one tube, which reduces the risk of contamination of samples and shares the advantages of both one-tube and one-step.

In conclusion, this study developed an one-step SYBR Green I real-time quantitative RT-PCR assay for detecting BVDV RNA in cell culture, which has high reproducibility and specificity, and is more sensitive than conventional RT-PCR. This method has developmental potentials in diagnosing and screening the animals infected with BVDV. It may also be applied to evaluate candidate agents against HCV using BVDV cell culture model.

\section{Acknowledgements}

This work was supported in part by the National Natural Science Foundation of China (Grant number: 81071371).

\section{Author details}

${ }^{1}$ Department of Infectious Diseases, First Affiliated Hospital, School of Medicine, Xi'an Jiaotong University, Xi'an 710061, Shaanxi Province, the People's Republic of China. ${ }^{2}$ Department of Microbiology, Molecular Genetics and Immunology, University of Kansas Medical Center, Kansas City, KS, USA. ${ }^{3}$ Institute of Endemic Diseases, School of Medicine, Xi'an Jiaotong University, Key Laboratory of Environment and Genes related to Diseases, Ministry of Education, Xi'an 710061, Shaanxi Province, the People's Republic of China.

\section{Authors' contributions}

NZ conceived and performed the experiments. ZL involved in conceiving and designing the experiments and writing the manuscript. $\mathrm{QH}$ contributed reagents and materials and involved in revising the manuscript. JQ and JC involved in designing the study and revising the manuscript. GZ, ZL, SL and $\mathrm{NL}$ involved in performing the experiments and data analysis. All authors read and approved the final manuscript.

\section{Competing interests}

The authors declare that they have no competing interests.
Received: 27 May 2011 Accepted: 29 July 2011 Published: 29 July 2011

\section{References}

1. Fulton RW, Burge $L$ : Bovine viral diarrhea virus types 1 and 2 antibody response in calves receiving modified live virus or inactivated vaccines. Vaccine 2001, 19:264-274.

2. Ridpath JF, Bolin SR, Dubovi EJ: Segregation of bovine viral diarrhea virus into genotypes. Virology 1994, 205:66-74.

3. Rice CM: Flaviviridae: the viruses and their replication. In Fields virology. Volume 1.. 3 edition. Edited by: Fields BN, Knipe DM, Howley PM. Lippincott-Raven Publishers, Philadelphia; 1996:931-960.

4. Colett MS, Larson R, Gold C, Strick D, Anderson DK, Purchio AF: Molecular cloning and nucleotide sequence of the pestivirus bovine viral diarrhea virus. Virology 1988, 165:191-199.

5. Choo QL, Richman KH, Han JH, Berger K, Lee C, Dong C, Gallegos C, Coit D, Medina-Selby R, Barr PJ, Weiner AJ, Bradleyt DW, Kuo G, Houghton M: Genetic organization and diversity of the hepatitis $C$ virus. Proc Natl Acad Sci USA 1991, 88:2451-2455.

6. Buckwold VE, Wei J, Wenzel-Mathers M, Russell J: Synergistic in vitro interactions between alpha interferon and RBV against bovine viral diarrhea virus and yellow fever virus as surrogate models of hepatitis $C$ virus replication. Antimicrob Agents Chemother 2003, 47:2293-8.

7. Buckwold VE, Beer BE, Donis RO: Bovine viral diarrhea virus as a surrogate model of hepatitis $C$ virus for the evaluation of antiviral agents. Antiviral Res 2003, 60:1-15.

8. Mars MH, Van Maanen C: Diagnostic assays applied in BVDV control in The Netherlands. Prev Vet Med 2005, 72:43-48, discussion 215-219.

9. Shannon AD, Richards SG, Kirkland PD, Moyle A: An antigen-capture ELISA detects pestivirus antigens in blood and tissues of immunotolerant carrier cattle. J Virol Methods 1991, 34:1-12.

10. Kennedy JA, Mortimer RG, Powers B: Reverse transcription-polymerase chain reaction on pooled samples to detect bovine viral diarrhea virus by using fresh ear-notch-sample supernatants. J Vet Diagn Invest 2006, 18:89-93.

11. Laamanen UI, Neuvonen EP, Yliviuhkola EM, Veijalainen PM: Comparison of RT-PCR assay and virus isolation in cell cultures for the detection of bovine viral diarrhoea virus (BVDV) in field samples. Res Vet Sci 1997, 63:199-203.

12. Renshaw RW, Ray R, Dubovi EJ: Comparison of virus isolation and reverse transcription polymerase chain reaction assay for detection of bovine viral diarrhea virus in bulk milk tank samples. J Vet Diagn Invest 2000, 12:184-186.

13. Gilbert SA, Burton KM, Prins SE, Deregt D: Typing of bovine viral diarrhea viruses directly from blood of persistently infected cattle by multiplex PCR. J Clin Microbiol 1999, 37:2020-2023.

14. Hilbe M, Stalder H, Peterhans E, Haessig M, Nussbaumer M, Egli C, Schelp C, Zlinszky $\mathrm{K}$, Ehrensperger F: Comparison of five diagnostic methods for detecting bovine viral diarrhea virus infection in calves. $J$ Vet Diagn Invest 2007, 19:28-34.

15. Bhudevi B, Weinstock D: Fluorogenic RT-PCR assay (TaqMan) for detection and classification of bovine viral diarrhea virus. Vet Microbiol 2001, 83:1-10.

16. Bhudevi $B$, Weinstock $D$ : Detection of bovine viral diarrhea virus in formalin fixed paraffin embedded tissue sections by real time RT-PCR (Taqman). J Virol Methods 2003, 109:25-30.

17. Mahlum CE, Haugerud S, Shivers JL, Rossow KD, Goyal SM, Collins JE, Faaberg KS: Detection of bovine viral diarrhea virus by TaqMan reverse transcription polymerase chain reaction. J Vet Diagn Invest 2002, 14:120-125.

18. Arikawa E, Sun Y, Wang J, Zhou Q, Ning B, Dial SL, Guo L, Yang J: Crossplatform comparison of SYBR Green real-time PCR with TaqMan PCR, microarrays and other gene expression measurement technologies evaluated in the MicroArray Quality Control (MAQC) study. BMC Genomics 2008, 9:328.

19. Schmittgen TD, Zakrajsek BA, Mills AG, Gorn V, Singer MJ, Reed MW: Quantitative reverse transcription-polymerase chain reaction to study mRNA decay: comparison of endpoint and real-time methods. Anal Biochem 2000, 285:194-204

20. Young NJ, Thomas CJ, Collins ME, Brownlie J: Real-time RT-PCR detection of Bovine Viral Diarrhoea virus in whole blood using an external RNA reference. J Virol Methods 2006, 138:218-222. 
21. Standardization Administration of the People's Republic of China: National standards of the P.R.C., diagnostic techniques for bovine viral diarrhea/ mucosal disease. First Editing Room of Standards Press of China, Collection of National Animal Health Standardization Standards Press of China, Beijing; 2004, 127-133.

22. Reed $L$, Muench AH: A simple method of estimating fifty percent endpoints. Am J Hyg 1938, 27:493-497.

23. Fronhoffs $S$, Totzke $G$, Stier $S$, Wernert N, Rothe M, Brüning T, Koch B, Sachinidis A, Vetter H, Ko Y: A method for the rapid construction of cRNA standard curves in quantitative real-time reverse transcription polymerase chain reaction. Mol Cell Probes 2002, 16:99-110.

24. van der Velden VH, Hochhaus A, Cazzaniga G, Szczepanski T, Gabert J, van Dongen JJ: Detection of minimal residual disease in hematologic malignancies by real-time quantitative PCR: principles, approaches, and laboratory aspects. Leukemia 2003, 17:1013-1034.

25. Ririe KM, Rasmussen RP, Wittwer CT: Product differentiation by analysis of DNA melting curves during the polymerase chain reaction. Anal Biochem 1997, 245:154-160

26. Scipioni A, Mauroy A, Ziant D, Saegerman C, Thiry E: A SYBR Green RT-PCR assay in single tube to detect human and bovine noroviruses and control for inhibition. Virol J 2008, 5:94

27. Drew TW, Yapp F, Paton DJ: The detection of bovine viral diarrhea virus in bulk milk samples by the use of a single tube RT-PCR. Vet Microbiol 1999, 64:145-154.

28. Weinstock D, Bhudevi B, Castro AE: Single-tube single-enzyme reverse transcriptase PCR assay for detection of bovine viral diarrhea virus in pooled bovine serum. J Clin Microbiol 2001, 39:343-346.

doi:10.1186/1743-422X-8-374

Cite this article as: Zhang et al.: Development of one-step SYBR Green real-time RT-PCR for quantifying bovine viral diarrhea virus type-1 and its comparison with conventional RT-PCR. Virology Journal 2011 8:374.

\section{Submit your next manuscript to BioMed Central and take full advantage of:}

- Convenient online submission

- Thorough peer review

- No space constraints or color figure charges

- Immediate publication on acceptance

- Inclusion in PubMed, CAS, Scopus and Google Scholar

- Research which is freely available for redistribution

Submit your manuscript at www.biomedcentral.com/submit 